\title{
The Effect of Marketing Mix, Service Quality and Trust on Customer Satisfaction and Loyalty at PT. Great Indonesian Milagros
}

\author{
Andi Nuryadin ${ }^{1}$, Mahfudnurnajamuddin², Sabri Hasan ${ }^{3}$, Mapparenta $^{4}$ \\ ${ }^{1}$ Doctoral Student in University of Muslim Indonesia (UMI), Makassar, Indonesia, \\ ${ }^{2}$ Professor in University of Muslim Indonesia (UMI), Makassar, Indonesia, \\ ${ }^{3,4}$ Associate Professor in University of Muslim Indonesia (UMI), Makassar, Indonesia.
}

Corresponding Author: Andi Nuryadin

\begin{abstract}
This research purposes aims to analyze the effect of the marketing mix (product, price, promotion, place, employee, process and physical evidence) on customer satisfaction, the effect of service quality on customer satisfaction, the effect of trust on customer satisfaction, the effect of the marketing mix on customer loyalty, the influence of quality. service to customer loyalty, the effect of trust on customer loyalty and the effect of satisfaction on customer loyalty at PT. Great Indonesian Milagros. Test and analyze the effect of the marketing mix on customer loyalty through customer satisfaction at PT. Great Indonesian Milagros. Test and analyze the effect of service quality on customer loyalty through customer satisfaction at PT. Great Indonesian Milagros. Test and analyze the influence of trust on customer loyalty through customer satisfaction at PT. Great Indonesian Milagros. To achieve this research, questionnaires were distributed and documents were collected using descriptive statistical analysis methods, SEM analysis. The total population is all customers who have registered in 2015-2019, amounting to 558 subscribers. The numbers of samples in this study were 233 customers. The results of this study found that the marketing mix and service quality have a positive and significant effect on customer satisfaction, trust has a negative and insignificant effect on customer satisfaction. The marketing mix, service quality, and Trust have a positive and significant effect on customer loyalty. Marketing mix and service quality have a positive and significant effect on customer loyalty through customer satisfaction.
\end{abstract}

Trust has a negative and insignificant effect on customer loyalty through customer satisfaction

Keywords: Marketing Mix, Service Quality, Trust, Customer Satisfaction, Customer Loyalty

\section{INTRODUCTION}

Drinking water processing is developing very fast and has changed people's lives in the modern era. The use of drinking water without cooking is not new anymore. The trend of instant life on all fronts stimulates scientists from all over the world to create practical technology, both in the process and in the final use of the product, of course, with the assurance of excellent quality and health standards. Entrepreneurs capture the opportunity by establishing bottled drinking water factories, one of which is PT. Great Indonesian Milagros. The number of company products that offer the same product variance makes the competition even tighter. It is only natural if a company in a hyper-competition period (high level and global competition) is currently preparing various activities to defend itself to continue to exist in the market. Every company carries out its marketing activities very seriously to win the competition among the key concerns of PT. Great Indonesian Milagros, in this case, are customer satisfaction and loyalty.

Consumer satisfaction is postpurchase behavior or product use. The form of customer satisfaction that can be seen 
empirically is re-purchase and recommendation. Customer satisfaction has become part of most companies' goals, in addition to obtaining the maximum profit or profit at once so that the company can face increasingly fierce competition to maintain the company's survival. According to Kotler and Keller (2016: 177), satisfaction is the level of feeling where a person states the results of comparing the pe-comparing product or service received and expected. In line with that, service companies' quality of service is essential to provide more satisfaction to customers and ultimately become an added value for the company. There is an assumption that arises regarding customer satisfaction. If it goes positive (consumers feel satisfied), the consumer will prefer to return to using the same company services when they need more services. Conversely, consumers who are not satisfied tend to leave the company.

When consumers assess satisfaction, it can be said and realized that consumers have different ratings in defining their satisfaction. By achieving customer satisfaction, it is expected that company revenue will increase. Customers will be loyal. The company can continue to grow in line with loyal customers'/customers' confidence in the long term. Customer loyalty will be the key for companies that want to win the competition, including in the highly competitive telecommunications industry. The development and improvement of telecommunication services from year to year is increasingly becoming a public concern. The results of the research which states that satisfaction affects customer loyalty are Piyakanit Chotivanich (2014), Ayu Atika Parmaitha Wendha (2013), Dean Michael (2010), Amir Mahmud (2013), Fachmi et al. (2020). Meanwhile, research that recommends that satisfaction has a negative and insignificant effect is Maxi Romeo (2008).

Customer satisfaction and loyalty do not automatically appear, so it takes effort to build and maintain customer satisfaction. Things that must be considered by companies in building and maintaining customer satisfaction are, among others by paying attention to the marketing mix, service quality, and customer trust. One of the best and right marketing strategies to implement is that companies can see the marketing mix factor. This is important because the marketing mix is one of the main considerations for making a product purchase decision. If the company is not sensitive to what consumers need marketing, the company will certainly miss many opportunities to get consumers, and the products offered will be in vain. In modern marketing concepts, many companies refer to the marketing mix in designing their marketing programs.

The marketing mix is one of the marketing tools used to achieve company goals. According to Tjiptono (2014: 41), a marketing mix is a set of tools that marketers can use to shape customers' services' characteristics. These tools can be used to develop long-term strategies as well as to design long-term tactical programs. The marketing mix's goal is to attract consumers by promising superior value, setting attractive prices, distributing products easily, promoting effectively, and maintaining the principle of customer satisfaction. Customer satisfaction is an important factor in creating customer loyalty. Loyal customers are assets for a company. Field facts show that the application of the 7P concept at PT. Great Indonesian Milagros is still low. Many flaws and weaknesses are found so that sometimes customers still complain and feel dissatisfied. Ideally, the application of the $7 \mathrm{P}$ theory put forward by Kotler and Keller (2016: 32) states that the 7P marketing mix (product, price, promotion, place, people, physical evidence, process) is an effective method of marketing products and services to customers. The effectiveness of the acceptance of the $7 \mathrm{P}$ marketing mix to customers is assessed based on the satisfaction and loyalty shown.

In addition to the marketing mix, there is no less important to increase 
customer satisfaction, and loyalty is the quality of service (service quality). According to Kotler (2016), the definition of service is any action or activity that a party can offer to another party, which is basically intangible and does not result in any ownership. Several studies are showing that service quality has a positive and significant effect on corporate image, namely Widiyanto and Juan Suam Toro (2012),. The results of research that show that service quality has a positive and significant effect on customer satisfaction are Tjiptono and Diana (2011), Ayu Atika Paramitha Wendha (2013), Setiawan \& Fachmi (2018), Fachmi et al. (2020) . In contrast, the results of research that show that service quality has a negative and insignificant effect on customer satisfaction and loyalty are Amir Mahmud (2013), which states that service quality has a negative and insignificant effect on satisfaction. This shows that service quality does not directly drive satisfaction.

Another factor that affects customer satisfaction and loyalty is customer trust in the products produced by the company. Trust is a foundation of a business. Trust is awareness and feeling that a customer has to trust a product and is used by service providers as a tool to build long-term relationships with customers (Diza, Moniharapon, \& Ogi, 2016). According to Norhermaya and Soesanto (2016), forming customer trust is one way to create and retain customers. According to Danesh, Nasab, and Ling (2012), trust is defined as a party's willingness to be vulnerable to the actions of other parties based on the expectation that the other party will take certain actions that are important to belief or regardless of the ability to monitor or control the other party. High trust by consumers in the company will be able to give consumers a sense of satisfaction in using the company's products or services, such as Widiyanto, who stated that customer trust is the foundation of a business which is a way to create and retain consumers (Laely, 2016,63). Diza, Moniharapon, and Ogi
(2016); Fachmi et al. (2020) found that trust positively and significantly affects customer satisfaction variables. Gul's (2014) research also proves that the trust variable has a significant effect on satisfaction.

The initial survey results indicated that there was still a small number of customers dissatisfied with the products marketed by PT. Great Indonesian Milagros. Customer dissatisfaction is an important problem for a company and must be addressed immediately. The existence of dissatisfaction felt by customers can impact customer trust that has been formed so far, which can also affect their satisfaction and loyalty.

\section{LITERATURE REVIEW}

The marketing mix is part of the marketing concept that has an important role in influencing consumers to buy the products or services offered. Kotler and Armstrong (2014: 76) define the marketing mix as follows, Marketing mix is the set of tactical marketing tools that the firm blends to produce the response it wants in the target market. Meanwhile, according to Kotler and Keller (2012: 119), a marketing mix is a set of marketing tools that companies use to achieve their marketing goals in the target market continuously. According to Kotler and Keller (2016: 47), in-service marketing has several marketing tools, namely Product (product), Price (price), Place (a place or distribution channel), Promotion (promotion), People (people), Physical Evidence (facilities). Physical), and Process (process). So it is known as "7P".

Besides that, service quality is also an important part of this research. Quality is one of the factors used by consumers to buy a product in the form of goods or services, in which a product can be compared with its competitors based on its quality. The value provided by customers is very strong based on the service quality factor. The quality of a product or service is the extent to which the product or service meets its specifications. According to Marcel (2013: 192), a service action's success is 
determined by quality. Quality is the highest appreciation of service action. Parasuraman et. al (2004), the theory of service quality dimensions, that quality service is a consideration for customers to fulfill customer satisfaction and loyalty. One of the service quality models that are widely used as a reference in marketing research is the ServQual (Service Quality) model as developed by Parasuraman, Zeithaml, and Berry (1985) in a series of their studies of six service sectors, repair, household appliances, credit cards, insurance, long distance telephone, automotive, retail and securities brokerage. ServQual (Service Quality) is built on the existence of a comparison of two main factors, namely customer perceptions of the real service they receive (Perceived Service) with the service that is actually expected or desired ((Expected Service).

Trust plays an important role in a relationship. Individuals have a tendency to judge others and decide whether to trust that person or not when engaging in interactions. Trust is a foundation of a business. Trust is awareness and feeling that a customer has to trust a product and is used by service providers as a tool to build long-term relationships with customers (Diza, Moniharapon, \& Ogi, 2016). According to Norhermaya and Soesanto (2016), forming customer trust is one way to create and retain customers. Customer trust is one of the factors that guides the formation of long-term relationships based on trust. Berry in Ismail (2014) states that the factors that are the basis for creating trust in the company are the perception of proficiency and honesty in the company. Then the research conducted by Berry, Parasuraman and Zeithaml stated that competence in service companies is an important tool that underlies consumer trust (Ismail, 2014), so that the indicators used in measuring consumer trust are (a) Company competence, (b) honesty. company, and (c) company reliability.

Kotler and Keller (2016: 177) who reveal that satisfaction is described as: "the level of feeling where a person states the results of a comparison of the performance of a product or service received and expected". Customer satisfaction has become a central concept in business discourse. Customers are the main focus in discussions about satisfaction and service quality. Therefore, customers play an important role in measuring satisfaction with the products and services provided by the company. The purpose of this definition is that if the performance of the product, whether goods or services, is much lower than the customer's expectations, the buyer can be said to be dissatisfied. Conversely, if the performance is in accordance with expectations or even exceeds expectations, the buyer will feel satisfied or very happy. According to Hidayat (2011), customer satisfaction (consumers) is the basic capital for companies in forming customer loyalty (consumers). Meanwhile, Wilkie (1996) states that satisfaction is an emotional response to an evaluation of the experience of consuming a product or service.

Customer loyalty is a description of customer attitudes and behavior towards a product, both in the form of goods and services provided by the company. Many business people will agree that achieving customer loyalty is a good thing. Loyal customers are better than customers who are less loyal. And having loyal customers usually pays dividends throughout the company's business journey. According to Tjiptono (2014: 110) is customer loyalty as a customer commitment to a brand, store, supplier based on a very positive attitude and is reflected in consistent repeat purchases. According to Oliver (2010: 128129) customer loyalty is a deep enduring customer commitment to re-subscribe or consistently repurchase selected goods / services in the future, even though the influence of the situation and marketing efforts have the potential to cause behavior change. Meanwhile, according to Widjaja (2014: 6) states that customer loyalty is customer attachment to a brand, shop, manufacturer, service provider, or other 
entity based on a favorable attitude and good responses such as repeat purchases.

By providing good service quality, affordable prices, and the quality of goods and services to consumers, it is assumed that it will positively and significantly affect company image, customer satisfaction, and loyalty. Based on literature review and previous research results, the following research hypothesis can be formulated:

1. Marketing mix has a positive and significant effect on customer satisfaction at PT. Great Indonesian Milagros.

2. Service quality has a positive and significant effect on customer satisfaction at PT. Great Indonesian Milagros.

3. Trust has a positive and significant effect on customer satisfaction at PT. Great Indonesian Milagros.

4. Marketing mix has a positive and significant effect on customer loyalty at PT. Great Indonesian Milagros.

5. Service quality has a positive and significant effect on customer loyalty at PT. Great Indonesian Milagros.

6. Trust has a positive and significant effect on customer loyalty at PT. Great Indonesian Milagros.

7. Customer satisfaction has a positive and significant effect on customer loyalty at PT. Great Indonesian Milagros.

8. Marketing mix has a positive and significant effect on customer loyalty through customer satisfaction at PT. Great Indonesian Milagros.

9. Service quality has a positive and significant effect on customer loyalty through customer satisfaction at PT. Great Indonesian Milagros.

10. Trust has a positive and significant effect on customer loyalty through customer satisfaction at PT. Great Indonesian Milagros.

\section{METHODS}

This study uses descriptive and quantitative research designs to analyze the marketing mix's effect, service quality, and trust on customer satisfaction and loyalty to drinking water at PT. Great Indonesian Milagros and the most influential statements in each variable. This study's population were all Milagros drinking water customers, namely in 2020, as many as 558 customers in 30 regions in Indonesia. The samples used as respondents in this study were 233 customers in the territory of Indonesia. The researcher then distributes questionnaires as one of the data collection techniques, in the form of a list of statements filled in by customers using a questionnaire list with a Likert scale. The alternative answers to positive values are 1 to 5 . The scoring is done on the respondent's answer then given a score using a scale Likert, such as on a scale of 5 (strongly agree), scale 4 (agree), scale 3 (quite agree), scale 2 (disagree), and scale 1 (strongly disagree).

Considering the research objectives, namely to analyze the effect of the marketing mix, service quality, and trust on customer satisfaction and loyalty, it will be analyzed qualitatively and quantitatively. The respondents' quantitative answers were processed using statistical analysis of the SPSS program version 21.00 and the AMOS program (Analysis of Moment Structures) version 21. Descriptive qualitative analysis was used to reveal descriptive descriptions of field data by interpreting the results of data processing through data tabulation in order to respond to the tendency of nominal empirical and descriptive data, such as; data on frequency, standard deviation, variance, and tendency to determine the state of nominal, ordinal and interval data. The descriptive analysis is useful for supporting the interpretation of the analysis results that have been carried out to discuss the research results. The quantitative analysis of the data analysis technique used in this study is the structural equation modeling (SEM). SEM is very useful in testing a series of relationships that have mutual dependence between variables simultaneously. One dependent variable can become an independent variable in the next equation relationship. 


\section{RESULT}

In this study, examining the assumptions underlying Structural Equation Modeling (SEM) is outliers, data normality, and linearity. The analysis results show that the mean and standard deviation (with the help of SPSS 21 software) is obtained that all research indicators have a mean value that is greater than the standard deviation so that all indicators do not contain outliers data. Therefore, all the indicators used in this study deserve to be analyzed to prove the hypothesis. Likewise, the data normality assumption examination results show that the critical value of $Z$ at $\alpha=0.05$ is 1.96). However, this assumption is not critical when the sample size is large. Referring to the Limit Central Theorem, if the sample size is getting bigger, the statistics obtained will be closer to the normal distribution. The sample size unit in this study is $\mathrm{n}=233$, which is considered to have met the Central Limit Theorem so that the assumption of normality can be ignored. Research that uses SEM analysis and requiring data normality assumptions also requires a linear relationship between variables. The test results show that what is used in this study is linear so that it can be analyzed further.
After fulfilling these criteria, the goodness of fit model is tested. The model is said to be good if empirical data conceptually and theoretically support a hypothetical model's development. The results of the SEM analysis at the initial stage that the significance level (p) of 0.000 indicates that the null hypothesis, which states that there is no difference between the sample covariance matrix and the estimated population covariance matrix, is rejected, with the rejection of the null hypothesis, it means that there is a difference between the sample covariance matrix and the matrix. The estimated population covariance, so the model is not yet feasible to use. Other indices (GFI, TLI, CFI, and RMSEA) also show the degree of resistance to the model. Therefore, based on the indication of modification indices, the modification was then carried out to improve the model to prove the hypothesis. Modification of the model is prioritized only on the correlation between items and errors and does not modify the influence path. The results of these modifications are presented in the final model in the following figure:

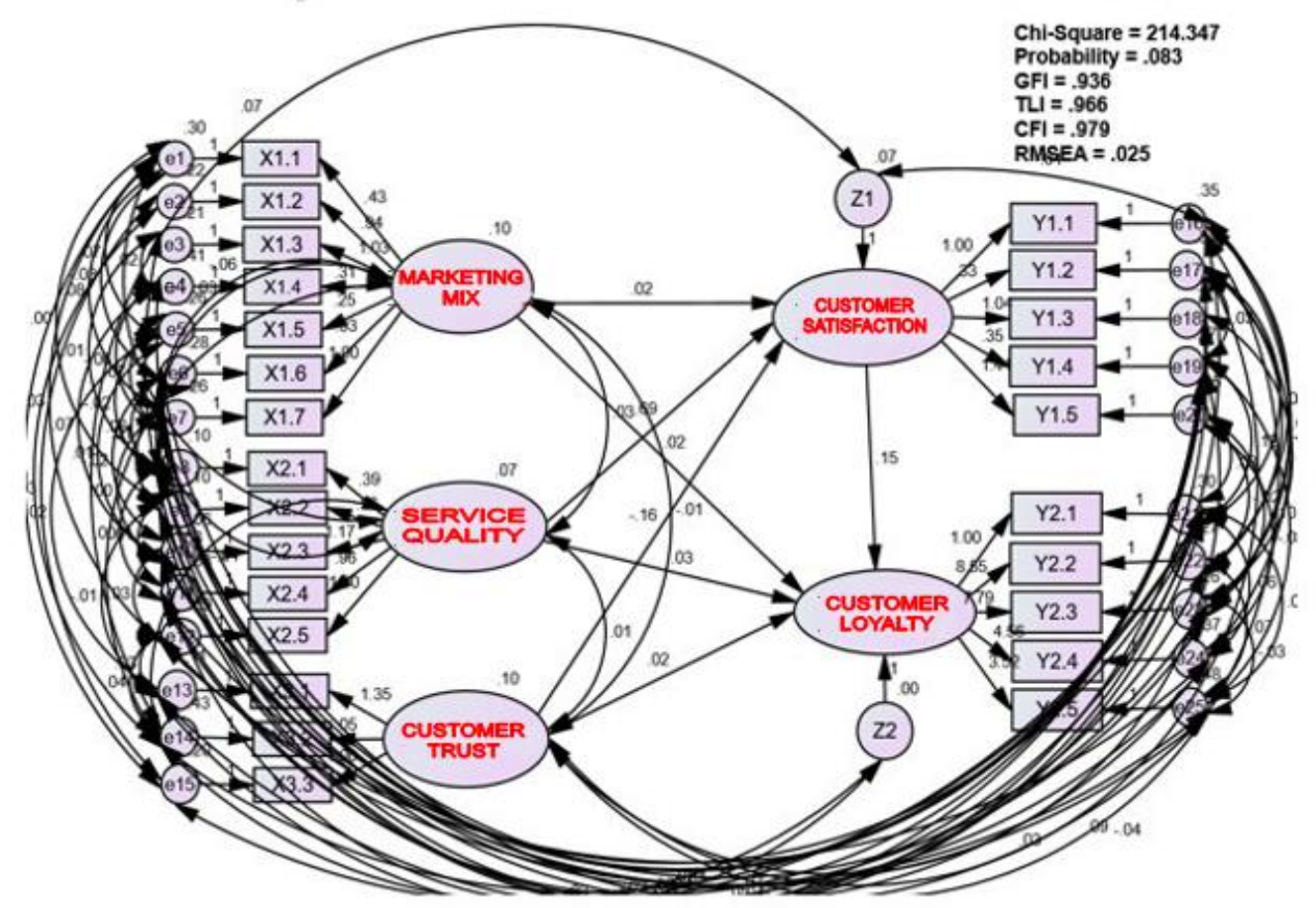

Figure 1: Final Model Hypothesis Test Results 
Andi Nuryadin et.al. The effect of marketing mix, service quality and trust on customer satisfaction and loyalty at PT. Great Indonesian Milagros.

Table 1: Hypothesis Testing Results

\begin{tabular}{|c|c|c|c|c|c|c|c|c|}
\hline \multirow[b]{2}{*}{ No } & \multicolumn{3}{|c|}{ Variable } & \multirow[b]{2}{*}{$\begin{array}{l}\text { Direct } \\
\text { Effects }\end{array}$} & \multirow[b]{2}{*}{$\begin{array}{l}\text { Inderect } \\
\text { Effect }\end{array}$} & \multirow[b]{2}{*}{$\begin{array}{l}\text { Total } \\
\text { Effect }\end{array}$} & \multirow[b]{2}{*}{$\begin{array}{c}\text { P- } \\
\text { Value }\end{array}$} & \multirow[b]{2}{*}{ Result } \\
\hline & $\begin{array}{c}\text { Independent } \\
\text { Variable }\end{array}$ & $\begin{array}{c}\text { Intervening } \\
\text { Variables }\end{array}$ & $\begin{array}{c}\text { Dependent } \\
\text { Variable }\end{array}$ & & & & & \\
\hline 1 & Marketing Mix & $\begin{array}{c}\text { Customer } \\
\text { Satisfaction }\end{array}$ & 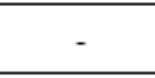 & 0.021 & 0 & 0.021 & 0.014 & $\begin{array}{c}\text { Positive and } \\
\text { Significant }\end{array}$ \\
\hline 2 & $\begin{array}{l}\text { Service } \\
\text { Quality }\end{array}$ & $\begin{array}{c}\text { Customer } \\
\text { Satisfaction }\end{array}$ & - & 0.578 & 0 & 0.578 & 0.000 & $\begin{array}{c}\text { Positive and } \\
\text { Significant }\end{array}$ \\
\hline 3 & Trust & $\begin{array}{l}\text { Customer } \\
\text { Satisfaction }\end{array}$ & - & $-0,151$ & 0 & $-0,151$ & 0.088 & $\begin{array}{l}\text { Negative and } \\
\text { Insignificant }\end{array}$ \\
\hline 4 & Marketing Mix & - & $\begin{array}{l}\text { Customer } \\
\text { Loyalty }\end{array}$ & 0,112 & 0 & 0,112 & 0.037 & $\begin{array}{c}\text { Positive and } \\
\text { Significant }\end{array}$ \\
\hline 5 & $\begin{array}{l}\text { Service } \\
\text { Quality }\end{array}$ & - & $\begin{array}{l}\text { Customer } \\
\text { Loyalty }\end{array}$ & 0.173 & 0 & 0.173 & 0.009 & $\begin{array}{c}\text { Positive and } \\
\text { Significant }\end{array}$ \\
\hline 6 & Trust & - & $\begin{array}{l}\text { Customer } \\
\text { Loyalty }\end{array}$ & 0.126 & 0 & 0.126 & 0.026 & $\begin{array}{c}\text { Positive and } \\
\text { Significant }\end{array}$ \\
\hline 7 & - & $\begin{array}{c}\text { Customer } \\
\text { Satisfaction }\end{array}$ & $\begin{array}{l}\text { Customer } \\
\text { Loyalty }\end{array}$ & 1,085 & 0 & 1,085 & 0.02 & $\begin{array}{c}\text { Positive and } \\
\text { Significant }\end{array}$ \\
\hline 8 & Marketing Mix & $\begin{array}{l}\text { Customer } \\
\text { Satisfaction }\end{array}$ & $\begin{array}{l}\text { Customer } \\
\text { Loyalty }\end{array}$ & 0.112 & 0.023 & 0.135 & 0.034 & $\begin{array}{c}\text { Positive and } \\
\text { Significant }\end{array}$ \\
\hline 9 & $\begin{array}{l}\text { Service } \\
\text { Quality }\end{array}$ & $\begin{array}{l}\text { Customer } \\
\text { Satisfaction }\end{array}$ & $\begin{array}{l}\text { Customer } \\
\text { Lovalty }\end{array}$ & 0.173 & 0.627 & 0.800 & 0.046 & $\begin{array}{c}\text { Positive and } \\
\text { Significant }\end{array}$ \\
\hline 10 & Trust & $\begin{array}{c}\text { Customer } \\
\text { Satisfaction }\end{array}$ & $\begin{array}{l}\text { Customer } \\
\text { Loyalty }\end{array}$ & 0.126 & -0.163 & -0.037 & 0.642 & $\begin{array}{l}\text { Negative and } \\
\text { Insignificant }\end{array}$ \\
\hline
\end{tabular}

Based on Figure 1, some of the final model goodness of fit test results for testing the hypothesis, it can be explained that the significance level (p) of 0.083 indicates that the null hypothesis states there is no difference between the sample covariance matrices. With the estimated population covariance matrix is acceptable, the acceptance of the null hypothesis means that there is no difference between the sample covariance matrix and the estimated population covariance matrix. Hence, the model is feasible to use. Other indices (GFI, TLI, CFI, and RMSEA) also show the model's level of acceptance. Therefore, the hypothesis testing refers to the final model, the results of which are presented in Table 1.

Based on Table 1, it can be explained that of the ten paths contained in the research model, there are eight paths that show a significant effect and two lines that show an insignificant effect. The results of processing with the SEM analysis model in the table show:

The hypothesis that the marketing mix has a positive and significant effect on customer satisfaction. This is evidenced by the positive regression coefficient of 0.021 and a significant value of 0.014 or greater than 0.05. This means that the marketing mix is given at PT. Great Indonesian Milagros has a positive and significant impact on customer satisfaction.

The hypothesis says that service quality has a positive and significant effect on customer satisfaction. This is evidenced by the positive regression coefficient of 0.578 and a significant value of 0.000 or less than 0.05 . This means that the quality of service is applied at PT. Great Indonesian Milagros has a positive and significant effect on customer satisfaction.

The hypothesis says that trust has a positive and significant effect on customer loyalty. This is evidenced by the negative regression coefficient equal to -0.151 and a significant value of 0.088 or greater than 0.05 . This means that the trust is applied in PT. Great Indonesian Milagros has a negative and insignificant effect on customer satisfaction.

The hypothesis says that the marketing mix has a positive and significant effect on customer loyalty. This is evidenced by the positive regression coefficient of 0.112 and a significant value of 0.037 or less than 0.05 . This means that the marketing mix is given at PT. Great Indonesian Milagros has a positive and significant effect on customer loyalty. 
The hypothesis says that service quality has a positive and significant effect on customer loyalty. This is evidenced by the positive regression coefficient of 0.173 and a significant value of 0.009 or less than 0.05 . This means that the quality of service provided at PT. Great Indonesian Milagros has a positive and significant effect on customer loyalty.

The hypothesis states that trust has a positive and significant effect on customer loyalty. This is evidenced by the positive regression coefficient of 0.126 and a significant value of 0.026 or less than 0.05 . This means that the trust is applied in PT. Great Indonesian Milagros has a positive and significant effect on customer loyalty.

The hypothesis states that customer satisfaction has a positive and significant effect on customer loyalty. This is evidenced by the positive regression coefficient of 1.085 and a significant value of 0.02 or less than 0.05 . This means that customer satisfaction is applied at PT. Great Indonesian Milagros has a positive and significant effect on customer loyalty.

The hypothesis says that the marketing mix has a positive and significant effect on customer loyalty through customer satisfaction. This is evidenced by the positive regression coefficient of 0.135 and a significant value of 0.034 or less than 0.05 . This means that the marketing mix is given at PT. Great Indonesian Milagros has a positive and significant impact on customer loyalty through customer satisfaction.

The hypothesis that service quality has a positive and significant effect on customer loyalty through customer satisfaction. This is evidenced by the positive regression coefficient of 0.800 and a significant value of 0.046 or less than 0.05 . This means that the marketing mix is given at PT. Great Indonesian Milagros has a positive and significant impact on customer loyalty through customer satisfaction.

The hypothesis that trust has a positive and significant effect on customer loyalty through customer satisfaction. This is evidenced by the negative regression coefficient, which is equal to -0.037 and a significant value of 0.642 or greater than 0.05 . This means that the trust is applied in PT. Great Indonesian Milagros has a negative and insignificant effect on customer loyalty through customer satisfaction

\section{DISCUSSION}

\section{The Effect of Marketing Mix on Customer Satisfaction}

Creating customer satisfaction is not easy because customer satisfaction can be created if the variables that will influence it, including marketing mix, service quality, trust, customer satisfaction, and customer loyalty, can be accommodated properly and accepted by all parties involved. This study's results can be seen from the results of the analysis on testing the effect of marketing odors on customer satisfaction. The analysis results show that the regression coefficient value is 0.021 and the probability $(\mathrm{p})=0.014$, which means that the marketing mix has a positive and significant effect on customer satisfaction because the significance value is less than 0.05 . Thus the hypothesis which states that the marketing mix has a positive and significant effect on customer satisfaction is accepted. This situation indicates that the marketing mix applied to PT. Milagros Indonesia Megah can increase customer satisfaction, especially those related to promotional indicators and processes that deal directly with customers, which results in customers feeling very satisfied with what is expected. The results of this study indicate that the application of the marketing mix is very influential on customer satisfaction; the results of this study also confirm that indicators of promotion and process indicate the indicators of the marketing mix based on customer responses at this time, that promotions and processes related to customers must be a special concern of the Milagros company. Great Indonesia so that 
customers feel satisfied, because other indicators of the marketing mix, namely product, price, location, employees, and facilities and infrastructure, are very supportive of serving customers. This study's results are in line with or support the results of research conducted by Reza Aril Ahri (2014), which found that the results of this study state that the effect of the marketing mix has a significant effect on customer satisfaction. While the research results of Pupuani N.W and Sulistyawati (2013), Wawor Valdy Ronald (2013) state that the marketing mix's effect has a significant effect on customer satisfaction. Meanwhile, the research results of Muhammad Haruna Isa (2015) and Garg, SA, Singh, H, and De, KK (2016) found that marketing mix has a positive and insignificant effect on customer satisfaction, contrary to the results of this study, which states that the effect of mix Marketing has a positive and insignificant effect on customer satisfaction.

\section{The Effect of Service Quality on Customer Satisfaction}

Service quality is a response to the superiority of services offered by PT. Great Indonesia Milagros through a comparison between the expected service and the service that is felt. The findings in this study indicate that service quality has a positive and significant effect on customer satisfaction. The analysis results show that the regression coefficient is positive, which is 0.578 . The probability (p) value is 0.000 or less than 0.05 , which means that service quality positively and significantly affects customer satisfaction at the 5\% significance level. Thus the hypothesis which states that service quality has a positive and significant effect on customer satisfaction is accepted. This situation shows that the quality of service is applied at PT. Milagros Indonesia Megah has been able to increase customer satisfaction, especially in terms of the company's seriousness in providing an explanation to customers about the benefits and advantages of Milagros water. The company guarantees service certainty and safety for customers who drink Milagros water. The company can display the best available facilities for customers, providing pleasant service to customers with full attention. One of the higher customer satisfaction is influenced by the better quality of service that is felt by customers because satisfaction is interpreted as customer feelings about the service performance provided, whether it is satisfactory and as expected (Fachmi \& Setiawan, 2020). The company is able to provide services by customer expectations regarding speed, punctuality, no errors, and a sympathetic attitude. The results of this study are in line with or support the results of research conducted by Kai Chieh $\mathrm{Hu}$ and Mei Chieh Huang (2011), Ching Lin Huang (2016), Florencia $\mathrm{T}$ Sia and Hartono Subagio (2013), Setiawan \& Fachmi (2018), Ayu Atika Paramitha Wendha (2013), Fachmi, et al. (2020) who found that Service quality has a positive and significant effect on customer satisfaction. Research results from Reza Aril Ahri (2014), Abduk Qadir Djaelani (2011), Harry Marcelino (2011) contradict the results of research which found that service quality had no significant effect on customer satisfaction. Service quality has a positive and significant effect on customer satisfaction, meaning that the better the customer has perceived service quality, the higher the customer satisfaction. Conversely, if the quality of service is perceived as low by customers, customer satisfaction is also low.

\section{The Effect of Trust on Customer Satisfaction}

Trust is a foundation of a business. Trust is awareness and feeling that a customer has to trust a product and is used by service providers as a tool to build longterm relationships with customers (Diza, Moniharapon, and Ogi, 2016). This study's results can be seen from the results of the analysis on testing the effect of trust on customer satisfaction. The analysis results show that the regression coefficient value is 
-0.151 and the probability $(\mathrm{p})$ value $=0.088$, which means that trust has a negative and insignificant effect on customer satisfaction or is greater than the 5\% significance level. Thus the hypothesis which states that trust has a positive and significant effect on customer satisfaction is rejected. This situation shows that the trust that is applied to PT. Milagros Indonesia Megah is not able to increase customer satisfaction. Trust has a negative and insignificant effect on customer satisfaction, meaning that the better the customer perceives trust, an increase does not follow customer satisfaction. This is, of course, different from Mayer, et al. in Fachmi \& Setiawan (2020), whose theory reveals that one of the factors forming a trust, namely ability, will provide a guarantee of satisfaction and security from the company. This means that building customer trust is important in order to increase customer satisfaction. Building trust is one of the big challenges for companies (Fachmi \& Setiawan, 2020). The existence of a negative influence is due to the fact that some customers have not perceived and understood well, especially in this discussion on indicators of goodness. This research is in line with Widiyanto and Juan Suam Toro's (2012) research, which states that trust has no significant effect on customer loyalty.

\section{The Effect of Marketing Mix on Customer Loyalty}

The marketing mix is part of the marketing concept, which has an important role in influencing customers to buy the products or services. According to Kotler and Keller (2012: 119), the marketing mix is a set of marketing tools that companies use to achieve their marketing goals in the target market continuously. The loyalty assumption theory put forward by Griffin (2005) states that evaluating loyal or disloyal customers is seen from the loyalty of making regular repurchases, and always recommending reference experiences to others for the services received, and showing positive responses to the services offered. The findings in this study indicate that the marketing mix has a positive and significant effect on customer loyalty, meaning that the better the marketing mix is perceived by the customer, then it is followed by an increase in customer loyalty. There is a positive influence because some customers have perceived and understood well about the picture in the form of products, prices, promotions, locations, employees, processes, physical facilities, customers recommending to others related to PT. Milagros Indonesia Megah, confident to be customers of PT. Milagros Indonesia Megah is not influenced by persuasion or promotion of competitors, so that customers repurchase Milagros brand drinking water products. This research is not in line with Reza Aril Ahri (2014), which states that marketing mix has a negative and significant effect on customer loyalty. This research is in line with research conducted by Owomo yela S. \& Oyeniyi.KO (2013), with The results, showed that the marketing mix has a significant effect on customer loyalty.

\section{The Effect of Service Quality on Customer Loyalty}

The research results indicate a relationship between service quality and customer loyalty, as shown by the path coefficient analysis, which means that there is an effect of service quality on customer loyalty. Thus the hypothesis that there is an influence of service quality variables on customer loyalty can be proven. This situation shows that the quality of service applied to PT. Milagros Indonesia Megah has been able to increase customer loyalty, especially in customers willing to repurchase. Customers are willing to recommend to prospective customers about the advantages and positive things about the Milagros Indonesia Megah company customers are not easy. They were influenced by the promotions and advantages of competing companies. The following describes the theory that supports this research, which is related to the effect 
of service quality on customer loyalty. Service quality is the delivery of services that will exceed customer interest level (Rangkuti, 2003: 28). In this definition, the provision of high-quality services meets and even exceeds customers' needs and expectations. Meanwhile, according to Parasuraman et al. (2004), the theory of service quality dimensions, that quality service is a consideration for customers to fulfill customer satisfaction and customer loyalty. The findings of this study are in line with research conducted by Harry Marcelino (2011), Abdul Qadir Djaelani (2011), Ayu Atika Paramitha Wendha (2013), Dean Michael (2010), Piyakanit Chotivanich (2014), Shary Shartykartini et al. (2016), namely service quality has a positive and significant effect on customer loyalty. Research findings that are contrary to the results of research conducted by Maxi Romeo (2008), Amir Mahmud et al. (2013), Muhammad Basir et al. (2015), Fachmi et al. (2020) namely that service quality have insignificant effect on customer loyalty.

\section{The Effect of Trust on Customer Loyalty}

The effect of trust on customer loyalty is very influential on the progress of a company. Customer satisfaction depends on the assumption that product performance in delivering value is relative to buyer expectations. When product performance is significantly lower than customer expectations, the buyer is dissatisfied. If the performance is as expected, the buyer will be satisfied. Satisfied customers will repurchase and they will tell people about a good experience about the product (Kotler and Armstrong 2010: 10). The results of testing the influence of the trust variable on customer loyalty through customer satisfaction with a p-value of 0.026 or less 0.05 and a positive regression coefficient value of 0.126 . This means that the trust applied in PT. Milagros Indonesia Megah has a positive and significant effect on customer loyalty, from the results of the research that trust has a positive and significant effect on customer loyalty, in accordance with the hypothesis which says that trust has a positive and significant effect on customer loyalty at PT. Great Indonesian Milagros. The results showed that trust has a significant effect on customer loyalty, trust has a positive and significant effect on customer loyalty, direct trust can have a significant effect on increasing customer loyalty in a high direction. This study is not in line with the research conducted by Widiyanto and Juan Suam Toro (2012), which states that trust has no significant effect on customer loyalty. However, this is in line with the research of Fachmi et al, (2020) that the higher the customer's trust, the more satisfaction they get.

\section{The Effect of Customer Satisfaction on Customer Loyalty}

The results of the study indicate that there is a relationship between customer satisfaction and customer loyalty as shown by the path coefficient analysis, which means that there is an effect of customer satisfaction on customer loyalty, thus the hypothesis which states that there is a variable effect of customer satisfaction on customer loyalty can be proven. The following describes the theory that supports this research, which is related to customer satisfaction's effect on customer loyalty. Satisfaction is the response or customer responses regarding meeting needs. Satisfaction is an assessment of the characteristics or features of a product or service, or the product itself, which provides a level of customer pleasure related to meeting customer consumption needs (Zethamal and Binner: 2000). The valuePercept theory views satisfaction as an emotional response triggered by an evaluation process that is cognitive or based on feelings (Parker and Mathew (2011). The opinion expressed by Virvilaite et al. (2009) states that satisfaction is the most important factor affecting customer loyalty. Scientists state that in a long-term relationship, customers expect high quality from the main service and additional benefits from 
continuing a relationship. This study's findings are in line with research conducted by Yunanto (2010), customer satisfaction has a positive and significant effect on customer loyalty. , Setyanto (2010, Rahyuda and Atmaja (2009), Hidayat Rachmad (2009), Al Muala.A. (2016), Harianto, D (2013), and Harry Marcelino (2011), Fachmi et al. (2020) the results of their research are that satisfaction has a positive and significant effect on loyalty. So satisfaction can increase the customer loyalty of PT. Milagros Indonesia Meg Ah. To increase customer loyalty, the Milagros Indonesia Megah company must continue to improve customer satisfaction by providing quality service in accordance with customer expectations.

\section{The Effect of Marketing Mix on Loyalty through Customer Satisfaction}

The results of testing the indirect effect of the marketing mix variable on customer loyalty through customer satisfaction with a p-value of 0.034 or less than 0.05 and a positive regression coefficient value of 0.135 . This means that the marketing mix applied at PT. Megah Indonesia Milagros has a positive and significant effect on customer loyalty through customer satisfaction. This study explains that customer satisfaction significantly acts as a mediator in explaining the effect of the marketing mix on customer loyalty, but based on the results of the examination to determine the type of mediation, the customer satisfaction variable in the research model is said to be not a mediating variable, meaning that the marketing mix has a significant effect on loyalty. customers, the marketing mix has a significant effect on customer satisfaction and customer satisfaction has a significant effect on increasing customer loyalty, so that without being supported by customer satisfaction, the marketing mix can directly have a significant effect on increasing customer loyalty in a high direction. This research is in line with research conducted by Ramin Rakhsha and M.Majidazar
(2011), which states that the application of the marketing mix supports increasing loyalty through customer satisfaction.

\section{The Effect of Service Quality on Loyalty through Customer Satisfaction}

The results of testing the influence of the service quality variable on customer loyalty through customer satisfaction with a p-value of 0.046 or less 0.05 and a positive regression coefficient value of 0.800 . This means that the quality of service implemented at PT. Milagros Indonesia Megah has a positive and significant effect on customer loyalty when through customer satisfaction from the results of this study that service quality has a positive and significant effect on customer loyalty, in accordance with the hypothesis that service quality has a positive and significant effect, significant towards customer loyalty through customer satisfaction at PT. Great Indonesia Milagros in Indonesia, then the ninth hypothesis is accepted. This study shows that the variable service quality has a positive effect on customer loyalty through customer satisfaction. It can be concluded that satisfaction will be created with satisfaction which is supported by good service quality. If the service quality of PT. Milagros Indonesia Megah matches or exceeds customer expectations, so customers will feel satisfied. Vice versa, if the service of PT. Megah Indonesia Milagros in Indonesia does not meet customer expectations, so customers will be disappointed and switch to using other products. If the customer is satisfied, it means that the quality is good, but if not satisfied then the quality is bad. This study contradicts the research of Abdul Qadir Djaelani (2011), The effect of service quality, price and service orientation on customer satisfaction and loyalty of Telkomsel Halo Card. The results showed that service quality had a negative and insignificant effect on satisfaction, but showed a positive and significant effect on customer loyalty. 


\section{The Effect of Trust on Loyalty through Customer Satisfaction}

The results of testing the influence of the trust variable on customer loyalty through customer satisfaction with a p-value of 0.642 or greater than 0.05 and a negative regression coefficient value of -0.037 . This means that the trust applied in PT. Milagros Indonesia Megah has a negative and insignificant effect on customer loyalty when through customer satisfaction from the results of this study that trust has a negative and insignificant effect on customer loyalty, it is not in accordance with the hypothesis that trust has a positive effect and significant towards customer loyalty through customer satisfaction at PT. Great Indonesia Milagros in Indonesia, then the tenth hypothesis is rejected. This is related to the high customer trust that will make the customer determine whether the customer will be loyal to the product used or will move to a product that offers more or in this case the indicator is not easily influenced. This shows that if one party trusts the other party, it will be possible to form a positive behavior and goodwill, in this case a good communication indicator. Therefore, when a customer has confidence in Milagros, the customer has the intention to buy the product again. In line with the research of Fachmi et al. (2020) that the higher the customer's trust, the more satisfaction they get, which leads to increased customer loyalty.

\section{CONCLUSION}

The results of this study found that the marketing mix has a positive and significant effect on customer satisfaction, service quality has a positive and significant effect on customer satisfaction, trust has a negative and insignificant effect on customer satisfaction, the marketing mix has a positive and significant effect on customer loyalty, service quality has a positive and significant effect on customer satisfaction. Customer loyalty is significant, trust has a positive and significant effect on customer loyalty and customer satisfaction has a positive and significant effect on customer loyalty. Marketing mix has a positive and significant effect on customer loyalty through customer satisfaction. Service quality has a positive and significant effect on customer loyalty through customer satisfaction. Trust has a negative and insignificant effect on customer loyalty through customer satisfaction.

Based on the results of the analysis and discussion, several suggestions can be made which can be used as a good consideration for the company PT. Milagros Indonesia Megah and other researchers and academics among them, in order to maintain and increase the number of customers, the company PT. Milagros Indonesia Megah must pay attention to the application of a marketing mix that deals directly with customers, especially those related to customer satisfaction. In addition, the company should provide a quality service that makes customers feel satisfied with the facilities they receive. Then, companies must also apply the marketing mix directly to customers so that customers feel the benefits of Milagros which can make customers loyal to the company.

\section{REFERENCES}

1. Amir Mahmud, Kamaruzaman Jusoff and St. Hadijah 2013. The Effect of Service Quality and Price on Satisfaction and Loyalty of Customer of Commercial Flight Service Industry. World Applied Sciences Journal 23(3): 354-359.

2. Ayu, A. P. W. 2013. Pengaruh Kualitas Layanan terhadap Kepuaan dan loyalitas Pelanggan Garuda Indonesia. Denpasar.

3. Bricci, L., Fragata, A., \& Antunes, J. 2016. The effects of trust, commitment and satisfaction on customer loyalty in the distribution sector. Journal of Economics, Business and Management, 4(2), 173177.

4. Danesh, S. N., Nasab, S. A., \& Ling, K. C. 2012. The study of customer satisfaction, customer trust and switching barriers on customer retention in Malaysia hypermarkets. International Journal of 
Business and Manage-ment, 7(7), 141150.

5. Dean Michael, 2010. Improvement Customer Satisfaction, Service Quality, Price and Service Orientation toward Increasing the Loyalty and Marketing Performance of General Hospital in New York. Marketing Management Journal, Vol. 17, p. 13-16

6. Fachmi, M., \& Setiawan, I. P. (2020). Strategi Meningkatkan Kepuasan Nasabah Analisis Kasus melalui Riset di Industri Asuransi Jiwa. CV. Pustaka Learning Center.

7. Fachmi, M., Modding, B., Kamase, J., \& Damis, H. (2020). The Mediating Role of Satisfaction: Life Insurance Customers' Perspective (Service Quality, Trust and Image Toward Loyalty). International Journal of Multicultural and Multireligious Understanding, 7(6), 156170.

8. Fachmi, M., Setiawan, I. P., \& Hidayat, A. (2019, October 14). Analysis of Factors Affecting Consumer Purchase Decision at Online Shops. https://doi.org/10.17605/OSF.IO/WV7M $\mathrm{U}$

9. Gul, R. 2014. The relationship between reputation, customer satisfaction, trust, and loyalty. Journal of Public Administration and Governance, 4(3), 368-387.

10. Ismail, Muhammad, 2014. Strategi Pemasaran Untuk Membangun Citra dan Loyalitas Merek, Cetakan Pertama, Penerbit : IPB Press, Kota Kediri.

11. Kotler, Philip dan Gary Armstrong, 2014. Principles Of Marketing, Edisi 14, New Jersey: Prentice-Hall Published.

12. Kotler, Philip and Kevin Lane Keller, 2016. Marketing Managemen, 15th Edition, Pearson Education,Inc.

13. Laely, N. 2016. Analisis Pengaruh Kepercayaan dan Harga Terhadap Loyalitas Pelanggan Dimediasi Kepuasan pada PT. Telkomsel di kota kediri. Jurnal Ilmu Ekonomi \& Manajemen, 3(2), 6174.

14. Leninkumar, V. 2017. The relationship between customer satisfaction and customer trust on customer loyalty.
International Journal of Academic Research in Business and Social Sciences, 7(4).

15. Lupiyoadi, Rambat. 2013. Manajemen Pemasaran Jasa: Berbasis Kompetensi. Jakarta: Salemba Empat.

16. Marcel, Davidson. 2010. Service Quality and Concept and Theory. Published by USA.

17. Maxi Romeo, 2008. Analysis of Customer Satisfaction, Price and Service orientation toward service quality and Loyalty by Customer.

18. Norhermaya, Y. A., \& Soesanto, H. 2016. Analisis Pengaruh Kepuasan Pelanggan Terhadap Kepercayaan dan Loyalitas Pelanggan untuk Meningkatkan Minat Beli Ulang (Studi Pada Online Store Lazada.co.id). Diponegoro Journal of Management, 5(3), 1-13.

19. Oliver, Harry. 2010. Measuring Customer Satisfaction; Survey Design, Uuse and tatistical Analysis Methods. ASQ Quality Press, Wisconsin, USA.

20. Parasuraman, Valarie, A, Zeitham, and L.L Berry. 1985.A Conceptual Model of Service Quality and Its Implication for Future Research. Journal of Marketing. Vol.49. pp 41-50.

21. Parasuraman, Valarie, A, Zeitham, and L.L Berry. 1988.SERVQUAL: A Multiple-Item Scale for Measuring Consumer Perception of Service Quality, Journal of Retailing, Vol. 64. No.1.

22. Piyakanit Chotivanich, 2014. Service Quality, Satisfaction and Customer Loyalty in A Full-Service Domestic Airline Thailand. International Journal of Art \& Sciences. Vol. 07(03): 161-169.

23. Rangkuti, Freddy, 2003. Measuring Customer Satisfaction : Teknik Mengukur dan Strategi Meningkatkan Kepuasan Pelanggan. PT. Gramedia Pustaka Utama. Jakarta.

24. Setiawan, I. P., \& Fachmi, M. (2018). Pengaruh Kualitas Pelayanan Terhadap Kepuasan Nasabah Pada PT. Bank Mega, Tbk Cabang Makassar Daya. SEIKO: Journal of Management \& Business, 1(2), 204-210. 
25. Tjiptono, Fandy dan Anastasia Diana. 2013. Total Quality Management. Edisi revisi, Penerbit Andi. Yogyakarta.

26. Tjiptono, Fandy. 2014. Pemasaran Jasa, prinsip, penerapan, penelitian.Yogyakarta: penerbit Andi.

27. Widjaja, Amin, 2014. Customer Relationship Mnagement: Manajemen hubungan pelanggan, konsep dan kasus. Jakarta : Harvarindo.

28. Widiyanto dan Juan Suam Toro, 2012. Analyisis of Influence of Service Quality and Price of Fairness With Customer Satisfaction, Customer Loyalty, Corporate
Image and Variable Trust As Mediation: Studies in Cunsomer PO. Rosalia Indah Surakarta. Fokus Manajerial, Vol. 11(2): 195-212.

29. Wilkie, W.L. 1990. Consumer Behavior, 2nded, John Wiley \& Sons. New York.

How to cite this article: Nuryadin A, Mahfudnurnajamuddin, Hasan $\mathrm{S}$ et.al. The effect of marketing mix, service quality and trust on customer satisfaction and loyalty at PT. Great Indonesian Milagros. International Journal of Research and Review. 2021; 8(2): 127-141. 